Discussion Paper No. 11-002

The Contribution of International R\&D to Firm Profitability

Bettina Peters and Anja Schmiele

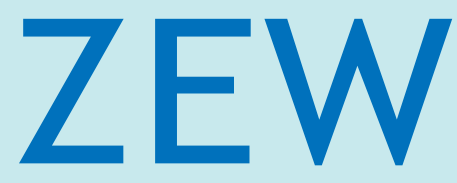

Zentrum für Europäische Wirtschaftsforschung $\mathrm{GmbH}$

Centre for European Economic Research 


\section{Discussion Paper No. 11-002 \\ The Contribution of International R\&D to Firm Profitability}

Bettina Peters and Anja Schmiele

Download this ZEW Discussion Paper from our ftp server:

ftp://ftp.zew.de/pub/zew-docs/dp/dp11002.pdf

Die Discussion Papers dienen einer möglichst schnellen Verbreitung von neueren Forschungsarbeiten des ZEW. Die Beiträge liegen in alleiniger Verantwortung der Autoren und stellen nicht notwendigerweise die Meinung des ZEW dar.

Discussion Papers are intended to make results of ZEW research promptly available to other economists in order to encourage discussion and suggestions for revisions. The authors are solely responsible for the contents which do not necessarily represent the opinion of the ZEW. 


\section{Non-Technical Summary}

Increased globalisation and competition caused more and more firms to relocate part of their $R \& D$ activities to foreign countries. This recent trend towards the internationalisation of $R \& D$ is motivated by expected gains through a better access to new knowledge, markets and more efficient production technologies. On the other hand, additional costs, e.g. for organising and coordinating dispersed activities, arise from the decentralisation of corporate R\&D.

Up to now, the empirical literature provides no evidence whether benefits do outweigh the financial and organisational costs of these international ventures. This research tries to fill this gap. Thus, the main question this paper tries to answer is whether international R\&D activities increase firms’ future profitability.

In order to shed light on the relationship between international R\&D activities and firm's profitability, we compare firms that have both domestic and international R\&D with firms that perform $R \& D$ only at the home country as well as with firms that do not carry out own $R \& D$ activities. Since the internationalisation of $R \& D$ is a growing phenomenon in a sense that not only more firms are going abroad but that also the number of foreign $R \& D$ centres has raised for many firms, we furthermore evaluate how the degree of internationalisation affects profitability. The degree of internationalisation is measured by the number of countries in which a firm performs R\&D abroad.

Our research makes use of information that is provided within the Mannheim Innovation Panel (MIP). The MIP is the official annual innovation survey among German firms, and it is the German contribution to the European-wide harmonised Community Innovation Surveys (CIS). Based on more than 1300 observations, we first of all find that firms performing R\&D in year 2005 make significantly higher profits in future years than firms without innovation activities. However, the stimulating effect on profitability is about twice as high for firms with domestic and foreign R\&D compared to firms that perform R\&D only in their home country. We can therefore conclude that firms which innovate globally are not only able to realise the benefits of these international ventures but that they are also able to limit the costs and risks. We furthermore provide evidence that firms with internationally more dispersed $R \& D$ operations achieve higher return on sales. However, a moderate number of R\&D locations abroad (2-3 countries) seems to be most conducive to profitability. Firms with four or more R\&D locations abroad seem to achieve lower profitability gains than medium centralized firms, but the profitability is still about twice as large as the one of firms performing solely domestic R\&D. 



\section{Das Wichtigste in Kürze}

Internationale Forschungs- und Entwicklungstätigkeiten bieten Unternehmen die Möglichkeit, weltweite Wissens- und Effizienzressourcen $\mathrm{zu}$ nutzen und neue Märkte besser zu erschließen. Zugleich bedeutet die Internationalisierung von FuE-Aktivitäten unter anderem jedoch auch eine Dezentralisierung der Kompetenzen und einen erhöhten Koordinierungsaufwand. Bei dieser Strategie, die Unternehmen infolge des zunehmenden weltweiten Wettbewerbs verstärkt anwenden, steht demnach der ungewisse Nutzen (FuETätigkeiten sind mit großen Risiken bezüglich ihrer Ergebnisse verbunden) steigenden Kosten gegenüber.

Die zentrale Fragestellung lautet daher, ob Unternehmen durch internationale FuE-Aktivitäten ihre Profitabilität steigern können. Die bestehende empirische Literatur liefert bislang keine Evidenz dahingehend, ob Unternehmen von internationalen FuE-Tätigkeiten finanziell profitieren oder ob die Kosten die Erträge übersteigen. Die vorliegende Studie schließt diese Forschungslücke.

Die Evaluation der Strategie der Internationalisierung von FuE-Prozessen hinsichtlich der zukünftigen Profitabilität von Unternehmen erfolgt mittels ökonometrischer Methoden. Dazu werden die Gewinne von Unternehmen, die nationale und internationale Forschungskapazitäten besitzen, verglichen mit den Gewinnen von Unternehmen, die ausschließlich nationale Forschung betreiben bzw. die keine eigene Forschung durchführen. Da nicht nur die Zahl der Unternehmen mit ausländischen Innovationsaktivitäten steigt, sondern auch die Anzahl der Auslandsstandorte innerhalb eines Unternehmens zunimmt, beleuchtet die Studie in einem zweiten Schritt, inwieweit sich ein größerer Grad an internationaler FuE-Dezentralisierung auf die Profitabilität auswirkt.

Die Ergebnisse auf Basis von mehr als 1300 deutschen Unternehmen im Rahmen des Mannheimer Innovationspanels zeigen zunächst, dass Unternehmen mit eigener FuE signifikant höhere Gewinne in den folgenden Jahren erzielen als Unternehmen ohne eigene Forschungsleistungen. Dieser positive Gewinneffekt ist für Unternehmen, die sowohl im Inals auch im Ausland FuE betreiben, jedoch etwa doppelt so hoch wie für Unternehmen, die Forschung nur im Inland durchführen.

Darüber hinaus weisen unsere Ergebnisse auf einen invers u-förmigen Verlauf zwischen dem Grad an internationaler Dezentralisierung von FuE und Profitabilität. Dies bedeutet, dass Unternehmen, die ausländische FuE in zwei bis drei Ländern durchführen, den höchsten 
Effekt auf die Umsatzrendite erfahren. Unternehmen mit FuE-Standorten in vier oder mehr Ländern weisen dagegen eine geringere Profitabilität auf als Unternehmen mit einem mittleren Dezentralisierungsgrad. Ihre Umsatzrendite ist aber dennoch deutlich höher als die von Unternehmen, die nur in Deutschland Forschung betreiben. 


\title{
The Contribution of International R\&D to Firm Profitability
}

\author{
Bettina Peters ${ }^{\text {a,b }}$ and Anja Schmiele ${ }^{\text {a,c }}$ \\ ${ }^{a}$ ZEW - Centre for European Economic Research \\ ${ }^{\mathrm{b}}$ Zurich University \\ ${ }^{\mathrm{c}}$ WHU - Otto Beisheim School of Management
}

January 2011

\begin{abstract}
The internationalisation of corporate $R \& D$ opens up the chances to participate in international knowledge sharing. This increasingly motivates firms to accelerate the pace and extent of their international R\&D activities in order to enhance innovativeness and consequently competitiveness and profitability. Such business ventures, however, might be associated with huge organizational costs as well as risks of outgoing knowledge spillovers. In this paper we empirically address the question whether international R\&D activities boost profitability. We employ a large data set of about 1300 firms from the German Community Innovation Survey (CIS). The empirical results demonstrate that R\&D location matters for profitability. Firms with both domestic and foreign R\&D activities make significantly higher profits than all other firms, including those that carry out solely domestic R\&D. We furthermore ascertain that the degree of $R \& D$ internationalisation affects profitability. Our findings suggest that medium decentralised firms which innovate in two or three foreign countries outperform firms with centralized or highly decentralized international R\&D strategies. Notwithstanding, decentralized firms achieve a higher firm performance than firms that solely conduct R\&D activities in their home country.
\end{abstract}

Keywords: R\&D, Innovation, Internationalisation, Firm performance, Profit

JEL-Codes: O32, F23

\section{Acknowledgements}

We are grateful to Georg Licht, Christian Rammer, Jürgen Weigand and participants at the INIR Workshop (Leuven, 2008), the Asigo Conference (Nuremberg, 2009), the European Association for Research in Industrial Economics (EARIE) Conference (Istanbul, 2010), the Technology Transfer (T2S) Conference (Washington, 2010) as well as at seminars at ZEW (Mannheim, 2009) and WHU (Vallendar, 2010) for helpful comments and suggestions on previous versions. All remaining errors are ours. 


\section{Introduction}

The profitability of a firm is an essential criterion to measure the effectiveness and success of firm operations. It reflects their ability to operate successfully in the competitive environment and therefore combines the results of firm strategy and execution as well as market response to firm output. In developed countries, the competitive advantage and performance of firms depends to a large extent on their ability to create new and innovative products (Hall, et al. 2009a).

In the search for new sources of technology and ideas firms increasingly expand their innovative capacities across borders (e.g. Kuemmerle, 1997; Florida, 1997; Granstrand et al., 1993). This has led to the growing internationalisation of corporate research and development (R\&D) activities in the last decade (UNCTAD, 2005). Firms equip their subsidiaries abroad with R\&D departments and set up centres of excellence in leading industry-specific locations. Due to the proximity to foreign knowledge resources that might not be available in the home country, firms seek to increase the chances to benefit from local knowledge spillovers. Absorbing and integrating additional knowledge allows firms to build an idiosyncratic knowledge base, improve their innovativeness and as a result to generate competitive advantages and higher profitability (Peteraf, 1993). Besides tapping new knowledge and searching for more efficient production technologies, firms seek to get better access to new markets and customers when relocating part of their $\mathrm{R} \& \mathrm{D}$ activities to foreign countries. All in all, the internationalisation of $\mathrm{R} \& \mathrm{D}$ reflects the global strategies of multinational enterprises (MNE) and the intention to look for new sources of competitiveness beyond domestic borders. Like any other business process, the internationalisation towards decentralised $R \& D$ activities is aimed at strengthening the economic performance of the firm.

Viewing the process to internationalise $R \& D$ from the cost perspective, these ventures may be associated with many barriers to profitability gains, ranging from set up costs, foregone economies of scale and scope, coordination costs, costs for intra-firm knowledge transfer, liabilities of foreignness or outgoing knowledge spillovers (Malecki, 1980; Zaheer, 1995; Gassmann and Von Zedtwitz, 1999; Andersson and Pedersen, 2010).

Hence, from a theoretical point of view, the relationship between international R\&D and firm profitability is ambiguous and has to be determined empirically. So far, however, the literature provides no large-scale empirical evidence on the profitability of foreign $R \& D$ activities. This research tries to fill this gap by assessing benefits and costs of international 
corporate R\&D activities. More specifically, we address the question of whether international $R \& D$ activities enhance future profitability. The answer to this question is naturally important from a managerial point of view since it allows them to assess the success of different corporate R\&D strategies. Evidence about the relation between gains and pains of international $R \& D$ activities is especially important against the background of growing international competition and a growing trend to carry out R\&D globally.

The empirical analysis is based on information collected within the Community Innovation Surveys (CIS) on a large sample of 1364 German companies for the period 2005-2008. In order to answer our research question, we compare the profit development of firms that have dispersed their $R \& D$ processes among foreign countries with that of firms conducting $R \& D$ only at home and performing no R\&D projects at all, respectively. Comparing profits of firms with or without foreign innovation activities comprises the overall assessment of both arising costs and benefits due to international R\&D activities. This approach thus demonstrates a complete view on firms' strategies to internationalise R\&D by considering both efforts and results of this business venture.

Our analysis contributes to the scant literature on international $R \& D$ and firm performance in the following three aspects. First, compared to previous studies we do not measure firm performance by means of productivity but use profitability instead. The fact that we do not compare the profit contribution of different R\&D locations within multinational enterprises but compare different R\&D strategies across firms is another main novelty of the paper. In line with the literature that examines the relationship between the degree of multinationality and firm performance, we thirdly investigate how the degree of $R \& D$ internationalisation affects profitability.

For this purpose the paper continues in the following sequence: section 2 reviews existing studies in this field of research, and it explores the theoretical frameworks which we use to derive our hypotheses. Section 3 introduces the dataset and focuses on the empirical approach to estimate the profitability of firms with international R\&D activities. The estimation results are presented in section 4 . Section 5 discusses the findings and concludes with management recommendations. 


\section{Literature Review}

\subsection{Internationalisation, R\&D and Firm Performance}

In a broader sense, our research ties on to two different strands of the literature. The first is the one that deals with the relationship between $R \& D$ activities and firm performance. Inspired by the seminal work by Griliches (1986), many studies have investigated the impact of $\mathrm{R} \& \mathrm{D}$ on productivity at the firm level. Most studies ascertain a significant positive private return to $\mathrm{R} \& \mathrm{D}$, ranging mostly between 20 to $30 \%$, and therefore feeding the widespread believe that R\&D is a key long-term driving force for competitiveness and growth of enterprises (see the survey by Hall et al. 2009b and the references cited therein). Using different measures of firm performance, Lööf and Heshmati (2006) find that R\&D and innovation activities are also conducive to both the level of firms' profits (after depreciation) and the growth rates of profits. The authors confirm such a positive R\&D effect for both manufacturing and service firms. Similarly, Czarnitzki and Kraft (2010) find a positive impact of the patent stock on profitability. Innovations thus allow firms to distinguish their products from competitors and as a result of this firms make higher profits (Kotabe et al., 2002). These studies, however, do not differentiate whether the location of R\&D activities matters.

Second, our research is related to the extensive literature that has investigated the effects of firms' geographical diversification on their performance (Vernon, 1971; Qian et al., 2008; Hitt et al., 1997; Wan and Hoskisson, 2003; Rugman and Verbeke, 2004; Kafouros et al., 2008; Gande et al., 2009). While some researchers have distinguished the degree of internationalisation by the number of firms' overseas subsidiaries (Qian et al., 2008; Hitt et al., 1994; Morck and Yeung, 1991), most studies defined it by using the share of international sales to total sales or foreign assets to total assets (see Qian et al., 2008 and Sullivan, 1994 for an overview). Concerning the measurement of firm performance, most scholars used the ratio of return on assets and return on sales (Sullivan, 1994; Kumar, 1984; Geringer et al., 1989). All in all, these studies come up with quite contradicting results ranging from negative or positive linear effects to horizontal s-curved or u-shaped relationships between firms' degree of internationalisation and firm performance (see Qian et al., 2008 and Sullivan, 1994). More importantly with respect to our research question, these studies do not take into account the kind of activities foreign subsidiaries perform. In particular, they neglect whether firms carry out innovation activities at their foreign subsidiaries. In a recent study, Kotabe et al. (2002) showed that MNEs with higher R\&D capabilities (R\&D intensity) benefit more from 
internationalisation. But this study likewise does not distinguish between the locations of R\&D activities of MNEs.

\subsection{Internationalisation of R\&D and Firm Performance}

\subsubsection{Potential Benefits from International $R \& D$}

The trend of firms to internationalise has developed from exporting to production and more knowledge intensive business processes. Foreign subsidiaries of MNEs do not act as prolonged sales entities of their mother company anymore but as units that often have implemented whole value chain processes including own R\&D activities. Basically, the literature invokes two streams of motives to explain why firms expand their R\&D activities to foreign countries around the world (e.g. Kuemmerle, 1997; Florida, 1997; Granstrand et al., 1993):

Foreign $R \& D$ activities are often a requirement of attractive markets in order to serve them with appropriate technologies and designs. Such demand-oriented motives result from the necessity to customise certain products to different foreign preferences, requirements or legal regulations. By tailoring products to local requirements, firms aim to enlarge their market size and generate higher profits by leveraging $R \& D$ outcomes across borders.

Supply-oriented motives are prevalent if firms want to make use of resources at foreign locations that are not available in the same quality or quantity as in the home country. In particular, resources such as knowledge and skilled employees drive firms' decision to perform R\&D activities abroad. Having R\&D departments in multiple countries enables firms to benefit from the pool of global knowledge resources. Foreign subsidiaries are usually embedded in local networks with customers, suppliers and competitors and are therefore linked to local knowledge, ideas and know-how (McEvily and Zaheer, 1999). Proximity to foreign knowledge sources enables foreign subsidiaries that carry out $R \& D$ activities to integrate the knowledge from the foreign business environment into their own innovation process either through co-operations or through incoming knowledge spillovers (Frost, 2001). Absorptive capabilities (Cohen and Levinthal, 1989) and knowledge sharing infrastructure allow firms to assimilate the foreign knowledge and enhance the learning process of the whole organization (Zahra and Hayton, 2008). Following the perspective and assumptions of the knowledge-based view, firms are bundles of knowledge and work as knowledge integrating institutions (Grant, 1996). Based on their corporate knowledge base, they can develop competitive advantages. In particular, the extent of competitive advantages depends 
on the uniqueness of the knowledge base. In this vein, multiple sources of knowledge open up better possibilities to firms to build an idiosyncratic knowledge base which incorporates additional knowledge, capabilities and know-how. Firms may increase their innovativeness by drawing upon this larger and improved knowledge base and can as a result develop and exploit competitive advantages. Increasing competitiveness and as a consequence also profitability are of course the final objectives of the strategy to internationalise corporate R\&D.

Recent empirical evidence has confirmed that domestic firms benefit on average from foreign R\&D activities by improving upon their innovation performance. Using a sample of MNEs performing R\&D abroad, Iwasa and Odagiri (2004) ascertain a positive contribution of international innovative $R \& D$ on patent output. Comparing firms with and without international $R \& D$, it has been shown that firms with foreign $R \& D$ produce more patents (Penner-Hahn and Shaver, 2005), are more successful in generating product innovations and achieve a higher innovation success in terms of higher sales growth rates due to new products than firms having only domestic R\&D activities (Peters and Schmiele, 2010). A related stream of literature examines the innovation performance of R\&D laboratories abroad and its drivers. Ambos and Ambos (2009) found that R\&D facilities in Non-Triad countries are less innovative and to a lesser degree (horizontally) integrated than foreign labs in Triad-nations. This relates to the finding of Phene and Almeida (2008) who identified knowledge from host country firms to increase the scale (number of patents) and quality (number of citations received) of subsidiary innovation. Furthermore, the relationship between the size of an R\&D site abroad and the performance of the lab turns out to be concave (Kuemmerle, 1998). Grevesen and Damanpour (2007) corroborate that knowledge sharing infrastructure in firms has a strong positive impact on innovation performance of foreign $R \& D$ subsidiaries.

\subsubsection{Costs of International R\&D Activities}

Depending on the organization of R\&D activities, different costs may arise. In general, the management of international dispersed $R \& D$ activities is characterized by a significantly higher degree of complexity than local R\&D management (Gassmann and Von Zedtwitz, 1999). On the one hand, a centralized organization is assumed to cause higher transaction costs (Coase, 1937; Williamson, 1985), costs to run information systems, opportunity costs for not responding to foreign market preferences and ignoring foreign resources. Running R\&D facilities abroad on the other hand involves various risks and costs since the 
internationalisation of $R \& D$ naturally represents a decentralisation of corporate innovation activities.

Besides direct set-up and infrastructure costs, the loss of economies of scale and scope are the primary concerns when R\&D activities are decentralized (Malecki, 1980). Economies of scale may arise if the research equipment is indivisible or if a critical mass of researchers is needed for a relatively efficient R\&D (Mansfield et al., 1979). Wallmaak et al. (1973) demonstrated that research efficiency increases exponentially with the research team size. If other typical headquarter activities such as marketing, trial production, testing, management of intellectual property rights or controlling are complementary to R\&D activities, a firm may not fully exploit these synergy effects if it shifts R\&D activities abroad (Sanna-Radaccio and Veugelers, 2007).

Instead of exploiting these economies of scale and scope, firms have to bear the extra costs of coordinating research between different $\mathrm{R} \& \mathrm{D}$ laboratories and coordinating work between foreign R\&D labs and headquarter activities. In general, minimal coordination costs would arise if the firm delegated autonomy and decision making to foreign R\&D divisions (Argryes and Silverman, 2004). But since knowledge produced in different R\&D locations is aimed to be shared across the whole organization, a certain degree of coordination is necessary (Leiponen and Helfat, 2010). Because monitoring R\&D activities abroad is much more difficult in distant locations, coordination is particularly important to avoid additional inefficiencies due to duplicative and redundant $R \& D$ projects that are more likely in rather decentralised international R\&D structures (Gassmann and Von Zedtwitz, 1999). All in all, the international decentralisation of corporate $R \& D$ activities urges innovative firms to tighten their control over foreign activities especially because R\&D activities represent their core competences. On the other hand, firms have to balance the likely benefits of coordinating research against the loss of independence and presumable innovativeness of foreign $R \& D$ laboratories.

Closely related is the argument that firms may be confronted with intra-firm knowledge losses. Researchers are most likely to share their knowledge when they work close to each other. More generally, knowledge spillovers are taking place rather within greater proximity than across long distances (Jaffe et.al., 1993; Branstetter, 2001). This finding can partly be explained by the characteristics of knowledge itself, i.e. the fact that new knowledge produced by research is often complex and is in part tacit and not codifiable (Zander and Kogut, 1995; Szulanski, 1996). Another reason might be that division R\&D managers may have little incentive to transfer knowledge across divisions, for instance if their compensation is tied to 
the performance of their divisions (Kay, 1988; Leiponen and Helfat 2010). As a result, firms may be confronted with a situation in which the knowledge existing in the R\&D centres is stuck within national borders. To overcome this problem, decentralised $R \& D$ structures require a high level of organisational costs related to managerial attention, efforts to establish knowledge sharing infrastructure, a strong facilitation of knowledge flows, for instance through knowledge exchanges and the establishment of incentives mechanisms to integrate subsidiary knowledge into the organizational knowledge base. Firms that have a small number of R\&D centres abroad might be less affected from these organisational problems than firms which have a global network of subsidiaries with R\&D mandates (Gassmann and Von Zedtwitz, 1999). ${ }^{1}$

In addition to these organisational expenses, firms may incur costs due to increasing outgoing knowledge spillovers. Foreign R\&D subsidiaries do not only source local knowledge but are also prone to knowledge leakage to local competitors. The extent of such spillover costs depends on the absorptive capacities of local competitors and the strength of product market competition on foreign markets (Sanna-Radaccio and Veugelers, 2007). Thus, to appropriate the results from $R \& D$ ventures abroad firms might also have to invest in stronger appropriability mechanisms.

Foreign business environments confront firms with additional complexity. The costs which arise from unfamiliar business environments (Hymer, 1976) are summarized in the concept of liabilities of foreignness (Zaheer, 1995). These costs result from cultural, political and economic differences which confront firms with unexpected situations and extraordinary risks. Furthermore, larger communication and organization costs due to the greater distance as well as a lack of networks and contacts constitute disadvantages in comparison to local firms abroad (Zaheer and Mosakowski, 1997). Therefore, liabilities of foreignness, as for example too much trust in formal contracts or local R\&D partners, are supposedly affecting the performance of firms with international $R \& D$ activities. In certain countries contracts are rather based on personal relationships and the respect of intellectual properties and their legal enforcement is not that embedded (Yang, 2005). The more the host country's culture differs from the culture of the firm's home country the higher these costs might be. Cultural distance is also emphasized by Hutzschenreuter and Voll (2008) as a driver of additional complexity in international expansion which evidently reduces firm performance.

\footnotetext{
${ }^{1}$ In this regard, Gassmann and Von Zedtwitz (1999) have observed the trend to recentralise international R\&D activities and rather establish an integrated R\&D network with a smaller number of leading R\&D labs. This cost reducing strategy enables firms to better utilise economies of scale and reduces redundant R\&D projects.
} 
All in all, the international phenomenon of decentralising $R \& D$ to foreign locations and specifically the tendency to an increasing number of R\&D locations abroad seems to worsen the corporate firm performance by raising various additional costs.

\subsubsection{Benefits versus Costs of International R\&D - Hypotheses}

In a theoretical approach Sanna-Radaccio and Veugelers (2007) combined both perspectives on international R\&D: benefits and costs. They highlight that shifting R\&D expenses abroad implies a cut in the R\&D budget at home (in the short run with fixed budgets) and therefore lowers the profitability of the parent company. This negative effect is at least partly offset by knowledge gains. Firms' profits from international R\&D thus strongly depend on two characteristics: i) on the knowledge transfer efficiency between the subsidiaries and the parent company and ii) on the extent to which incoming knowledge spillovers from the foreign business environment exceed outgoing spillovers. Therefore, the influence of the symmetry between costs and benefits resides to a major extent in the hand of firms in terms of optimising knowledge flows and limiting knowledge spillovers to foreign competitors. If the firm can master the risks of local competition and knowledge leakage and encourage international incoming knowledge spillovers, then a positive impact on profits can be expected.

Since the relation between the gain and the pain of international $R \& D$ remains theoretically ambiguous, it has to be determined empirically. We formulate two sets of hypotheses. Following the knowledge-based view, we hypothesize that firms that set up R\&D facilities abroad benefit from a better access to foreign knowledge pools that increase their innovativeness and subsequently their competitive advantage and profitability. In this vein, a stronger decentralisation of R\&D should increase profitability as it allows firms to tap and combine knowledge from multiple sources. We implicitly assume that these firms possess an appropriate amount of resources and intercultural experience to set up both sufficiently efficient intra-firm coordination and knowledge transfer mechanisms and sufficiently efficient knowledge protection methods to prevent outgoing knowledge spillovers.

H1a: The benefits outweigh the costs of international $R \& D$ and lead to a greater profitability of firms with international dispersed $R \& D$ activities compared to firms which perform R\&D only at the home base.

H2a: Firms that have dispersed their $R \& D$ activities in a wider range of foreign locations benefit from the access to a greater knowledge pool and as a result they make higher 
profits than firms which concentrated $R \& D$ activities in a small number of locations abroad.

The alternative hypotheses follow the arguments of foregone economies of scale and scope, outgoing spillovers, liabilities of foreignness, added cultural distance and increasing organisational costs:

H1b: International R\&D activities drive corporate costs extraordinarily high, so that costs exceed benefits and therefore affect the firm profitability negatively compared to firms which perform R\&D only at the home base.

H2b: Firms that have dispersed their $R \& D$ activities in a wider range of foreign locations incur proportionately high costs and thus larger losses in profitability than firms which concentrated $R \& D$ activities in a small number of locations abroad.

Sanna-Radaccio and Veugelers (2007) stated that the profitability of foreign R\&D activities decreases with strong host product market competition. With strong product market competition local rivals exhibit a stronger absorptive capacity which increases the risk of knowledge leakage. This raises the cost of outgoing knowledge spillovers and reduces profitability if spillovers are asymmetric (sufficiently in disfavour of the MNE).

H3: The profitability of foreign $R \& D$ activities declines with strong competition on the host product market.

\subsubsection{Empirical Evidence}

Studies which have examined the effects of international R\&D activities on firm performance - to the best of our knowledge to-date - have investigated the impact on productivity growth. In this vein, Mansfield (1984) ascertained for a sample of 15 US MNEs that foreign R\&D has a positive impact on productivity of home-country US plants. Fors (1997), however, could not confirm this result for Swedish MNEs. He found that both R\&D at home and R\&D at foreign subsidiaries show the same rate of return on productivity growth for the respective firm entity. Furthermore, he provided evidence that R\&D performed at home increases productivity in foreign plants. However, there is no indication of a knowledge transfer in a sense that home plants benefit from R\&D abroad. Fors argued that this finding can be expected if foreign $R \& D$ is mainly adaptive, i.e. geared towards the exploitation of existing knowledge. However, due to data constraints he was not able to cope with different types of R\&D activity in foreign subsidiaries. Todo and Shimizutani (2008) approached this research gap by analyzing the effects of adaptive and innovative (knowledge augmenting) R\&D activities 
abroad on productivity growth in the home country. Using data for Japanese MNEs, they found a positive impact of innovative $R \& D$ on home productivity growth. In contrast, adaptive foreign $R \& D$ does not raise the parent firm's productivity growth. Interestingly, they did not detect any positive interaction between home and foreign $R \& D$ activities on parent firm's productivity growth.

Our aim is to contribute to the scant literature on international $R \& D$ and firm performance in the following aspects: First, instead of focussing on productivity performance, the present paper is aimed at investigating how firms' profitability is influenced by international $R \& D$ activities. Furthermore, we investigate how the degree of $R \& D$ internationalisation affects profitability.

\section{Data and Empirical Implementation}

\subsection{Data}

For the empirical test of our hypotheses we need firm-level information about corporate $R \& D$ activities in the home and host countries and data about the development of firm profitability. Appropriate data sources for our purpose are the official German innovation surveys, called Mannheim Innovation Panel (MIP). Since 1993, the surveys are conducted on a yearly base by the Centre of European Economic Research (ZEW), the Fraunhofer Institute for Systems and Innovation Research (ISI) and the Institute for Applied Social Sciences (infas) on behalf of the German Federal Ministry of Education and Research (BMBF). The MIP targets firms with at least 5 employees across manufacturing and service sectors and with headquarters in Germany. Every second year (prior to 2005: every fourth year) the data set is also incorporated in the European-wide harmonized Community Innovation Surveys (CIS). The CIS put detailed questions to firms on their innovation efforts, innovation success and other innovation related topics. Usually, however, the MIP goes beyond the extent of the core CIS questionnaire and poses additional questions. The 2006 survey, for instance, included detailed questions on R\&D activities outside the home country. In 2006, the survey was sent out to 17,395 firms in Germany and a response rate of about 30\% was achieved. ${ }^{2}$ Since the MIP is designed as a panel, it allows us to merge firm-level information across different waves, using

\footnotetext{
${ }^{2}$ Additionally, a non-response sample of about 4000 firms was asked by telephone on core innovation indicators to account for non-response bias.
} 
distinct identifying numeric codes for surveyed firms. More detailed information about the data can be found in Peters (2008) or Peters and Schmiele (2010).

In the present paper we make use of two survey waves from the MIP panel. We gather information about firms' innovation activities abroad in year 2005 from the 2006 survey. In this survey firms were asked what type of innovation activity they perform abroad, dividing between different categories (R\&D, implementation of new processes, conception/design/construction of new products, manufacturing of new products, sales of new products). For each type of innovation activity, firms were furthermore requested to name in a free text field the countries in which they predominantly perform it. The 2009 survey provides us with information about firms’ profitability in the year 2008.

\subsection{Dependent Variable}

We aim at measuring the impact of international R\&D activities on future profitability. Since it takes time to translate research efforts into new products or processes, success variables like profitability need to be measured in appropriate time after the operations, to be evaluated where executed. In order to create a sufficient time lag between the $R \& D$ activities abroad and the performance indicator, we employ the latest available survey data to measure profitability. That is, we use the 2009 survey that includes firm profitability in 2008. Since empirical evidence has pointed towards the fact that firms tend to carry out rather applied instead of basic R\&D at foreign locations, a three-year time lag between research efforts and performance indicator seems to be reasonable. This approach might also alleviate potential endogeneity problems due to simultaneity of the decision to locate $R \& D$ and profitability that would arise in a cross-sectional analysis.

Profitability is measured using profit margins, more precisely the earnings before taxation as a share of total sales in 2008. The return on sales has been captured in the survey by offering the respondents the possibility to choose their answer from a set of eight possible categories ( $<0 \%, 0 \%-<2 \%, 2 \%-<4 \%, 4 \%-<7 \%, 7 \%-<10 \%, 10 \%-<15 \%,>=15 \%$, unknown). By using this information we create a time lag of three years between our dependent variable (profitability in year 2008) and the foreign R\&D activities in 2005. 


\subsection{Explanatory Variables}

\subsubsection{Measuring Domestic and International R\&D Activities}

The main focus of our paper is to evaluate firms' strategies to locate R\&D activities abroad. In order to test the first two hypotheses, we include two binary variables (see Table 1 for detailed definition): The first dummy indicates firms that concentrate their R\&D activities at their home location (firms with domestic $R \& D$ only). The second dummy variable equals one if the firm carries out national and international $\mathrm{R} \& \mathrm{D}$ activities (firms with domestic and foreign $R \& D$ ). Because only one firm reports foreign but no domestic $R \& D$ activities, we cannot test for complementarity between the two strategies.

As already pointed out in the literature review, the total benefits and costs may vary with the extent of foreign $R \& D$ activities. For instance, on the one hand a greater number of $R \& D$ locations abroad imply a better chance to source knowledge from a wider range of locations. On the other hand it may increase coordination costs. In order to be able to investigate the effect that international $R \& D$ intensity exerts on firm performance, we also include three dummy variables that capture the degree of $R \& D$ internationalisation. Similar to previous studies in the research field of firm internationalisation and firm performance, we define the degree of R\&D internationalisation by using the number of countries in which the firms run $\mathrm{R} \& \mathrm{D}$ laboratories. We receive the information about the number of countries in which the firms operate their R\&D activities from the MIP survey. We distinguish between centralized, medium decentralized and decentralized foreign $R \& D$ activities in accordance with a situation in which a firm carries out $R \& D$ in one, two to three and more than three foreign countries.

Furthermore, note that we employ a representative sample of all firms - but not all firms have conducted R\&D in 2005. We construct two additional dummy variables to identify two different groups of non-R\&D performing firms. The first group comprises firms that are engaged in innovation activities but without carrying out own intramural R\&D activities (firms without $R \& D$ ). The second group indicates firms with no innovation activities in 2005 (firms without innovation activities). In the estimates, innovative firms without $R \& D$ present the reference category. 
Table 1: Definition of Domestic and International R\&D Activities

\begin{tabular}{|c|c|}
\hline Innovation activities in year 2005 & Definition \\
\hline Firms without innovation activities & $\begin{array}{l}1 \text { if the firm is not engaged in any technological } \\
\text { innovation activities in year } 2005\end{array}$ \\
\hline Firms without R\&D (reference group) & $\begin{array}{l}1 \text { if the firm is engaged in other innovation activities } \\
\text { except for intramural R\&D activities in 2005, e.g. } \\
\text { extramural R\&D activities, acquisition of external } \\
\text { knowledge or machines, design, product testing and } \\
\text { preparation. }\end{array}$ \\
\hline Firms with domestic R\&D only & $\begin{array}{l}1 \text { if the firm performs intramural R\&D activities only } \\
\text { in Germany in } 2005\end{array}$ \\
\hline Firms with domestic and foreign R\&D & $\begin{array}{l}1 \text { if the firm performs intramural R\&D activities in } \\
\text { Germany and at least in one R\&D laboratory abroad }\end{array}$ \\
\hline Firms with centralised foreign R\&D & 1 if the firm has an R\&D lab in only 1 country abroad \\
\hline Firms with medium decentralised foreign R\&D & 1 if the firm has R\&D labs in 2 or 3 countries abroad \\
\hline Firms. with decentralised foreign R\&D & $\begin{array}{l}1 \text { if the firm has R\&D labs in } 4 \text { or more countries } \\
\text { abroad }\end{array}$ \\
\hline
\end{tabular}

\subsubsection{Control Variables}

The estimation additionally includes a number of firm-level control variables that previous research had linked to profitability. Table 2 summarises all control variables and provides more details on their definitions. First, we account for different aspects of the competitive environment in which firms operate and that may influence profitability. We define a binary variable that captures whether firms face strong international competitors. This information stems from the survey and we expect a negative sign on profitability. In order to test hypothesis $\mathrm{H} 3$ that foreign $\mathrm{R} \& \mathrm{D}$ activities are less profitable if product market competition in host countries is fierce, we additionally interact this variable with the variable indicating foreign $R \& D$ activities (firms with foreign $R \& D$ x strong international competition). Another aspect of the competitive environment is whether technological competition is characterised by fast outdated products (fast obsoletion). The sign of this variable is a priori unclear. Firms operating in markets where products become rapidly obsolete due to strong technological competition might charge higher prices and earn higher profits since the expected time to reap benefits from innovative products is shorter. On the other hand, strong competition might prevent them from earning higher profits. We further include the firm's market share that reflects market power. Higher market shares are expected to alter the level of sales and profitability and therefore need to be accounted for. Since firms could tick a box in the survey if their market share is below $0.1 \%$, we set the market share to zero for these firms and additionally create a dummy variable to account for the truncation effect (market share truncated). Similarly, we create a dummy variable for those firms for which this information is missing (market share missing). 
The estimation also contains a dummy variable that indicates whether the firm exports to foreign markets in the year 2005 (exporter). By and large, the literature on exports and firm performance provides evidence that a positive correlation between exports and firm performance is due to the fact that the best performing domestic firms self-select into international markets (Bernard and Jensen 1999; De Loecker, 2007). A similar argument might be effective in case of international R\&D. Past profitability is likely to be correlated with future profitability (Geroski and Jacquemin, 1988) and it might also be correlated with the decision to perform R\&D abroad in a sense that the most profitable firms self-select into the sample of international R\&D performing firms. In this case, omitting past profitability would render the variable international $R \& D$ endogenous. We account for past profitability by including eight dummy variables that measure firms’ profit margins in 2005.

Another set of controls are two dummy variables that are intended to capture the effect of marketing and organisational innovations on firm profitability. Marketing efforts of firms have been proved to enhance the operational performance of multinational firms (Kotabe et al., 2002). The introduction of new brands, sales channels, designs and pricing strategies might enable firms to distinguish their products from competitors and as a result to reap higher profits. Similarly, organisational innovations such as (changes in) knowledge management, customer relationship and alliance management might stimulate firm profitability.

In addition, we control for firm size (number of employees in 2005), the degree of diversification of firms' production and the capital intensity. The capital intensity points to the level of assets which, when they are used efficiently, contribute to firm performance (Harris, 1988). We measure capital intensity by the ratio of the value of fixed assets to employees in year 2005. Other control variables account for the type of ownership. We distinguish between unaffiliated firms (reference group) and firms that either belong to a national group, international group with a German headquarter or an international group with headquarter abroad. The latter firms might be more likely to have $R \& D$ at their foreign sites close to their head offices. Dummies for firms belonging to high $R \& D$-intensive manufacturing, medium $R \& D$-intensive manufacturing, low $R \& D$-intensive manufacturing, knowledge-intensive services and other services (reference category) allow us to control for industry effects. The categorization of industries has been done following the method of Legler and Frietsch (2007) for the Federal Ministry of Education and Research to distinguish industries by their level of R\&D intensity and knowledge intensity. 
Table 2: Definition of Control Variables

\begin{tabular}{|c|c|}
\hline Control Variables related to year 2005 & Definition \\
\hline Firm size & No. of employees (in log) \\
\hline Degree of diversification & $\begin{array}{l}1 \text { divided by the share of sales with the most important } \\
\text { product }\end{array}$ \\
\hline Capital intensity & Ratio of firms' tangible fixed assets to total employees \\
\hline Exporter & 1 if the firm is exporting to markets abroad \\
\hline National group & 1 if the firm is part of a national group \\
\hline Intern. group with German HQ & $\begin{array}{l}1 \text { if the firm is part of an international group headquartered in } \\
\text { Germany }\end{array}$ \\
\hline Intern. group with HQ abroad & $\begin{array}{l}1 \text { if the firm is part of an international group headquartered } \\
\text { abroad }\end{array}$ \\
\hline Previous profits $i$ & $\begin{array}{l}\text { Firm's return on sales ratio in year } 2005 \text {; }(i \text { has one of eight } \\
\text { values: }<0 \% \text {; } 0-2 \% \text {; } 2-4 \% \text {; } 4-7 \% \text {; } 7-10 \% ; 10-15 \% ;>15 \% \text {; } \\
\text { information unavailable. The reference category is }<0 \% \text { ) }\end{array}$ \\
\hline Industry & Industry classification is based on Legler and Frietsch (2007) \\
\hline High R\&D-intensive manufacturing & $\begin{array}{l}1 \text { if the firm belongs to high R\&D intensive manufacturing } \\
\text { (NACE } 3 \text { digit: 233, 242, 244, 296, 300, 321-323, 331-333, } \\
\text { 353) }\end{array}$ \\
\hline Medium R\&D-intensive manufacturing & $\begin{array}{l}1 \text { if the firm belongs to medium R\&D intensive } \\
\text { manufacturing (NACE } 3 \text { digit: 241, 246, 251, 291, 293-295, } \\
\text { 311, 312, 314-316, 334, 341, 343, 352) }\end{array}$ \\
\hline Low R\&D-intensive manufacturing & $\begin{array}{l}1 \text { if the firm belongs to low R\&D intensive manufacturing } \\
\text { (NACE } 3 \text { digit: } 150-455 \text {, except for those industries already } \\
\text { counted as high and medium R\&D intensive manufacturing) }\end{array}$ \\
\hline Knowledge-intensive services & $\begin{array}{l}1 \text { if the firm belongs to the knowledge-intensive service sec- } \\
\text { tors (NACE } 3 \text { digit: 221, 523, 603, 611, 622, 623, 643, 651, } \\
652,660,671,701,721-726,731,732,741-744,921-925 \text { ) }\end{array}$ \\
\hline Other services (reference group) & $\begin{array}{l}1 \text { if the firm belongs to other service sectors (not counted as } \\
\text { knowledge-intensive service sector) }\end{array}$ \\
\hline \begin{tabular}{|l|}
$\begin{array}{l}\text { Control Variables related to years } \\
2006-2008\end{array}$ \\
\end{tabular} & Definition \\
\hline Marketing innovation & $\begin{array}{l}1 \text { if firm has introduced at least one marketing innovation } \\
\text { (improved design, advertising techniques / media, sales } \\
\text { channels, price policy) }\end{array}$ \\
\hline Organisation innovation & $\begin{array}{l}1 \text { if firm has introduced at least one organisation innovation } \\
\text { (efficient business organisation, work organisation, external } \\
\text { relationship management) }\end{array}$ \\
\hline Control Variables related to year 2008 & Definition \\
\hline Market share & Market share of most important product \\
\hline Dummy: Market share truncated & 1 if market share is below $0.1 \%$ \\
\hline Dummy: Market share missing & 1 if market share information has not been specified \\
\hline Competitive Environment & \\
\hline Competition: Fast obsoletion & $\begin{array}{l}1 \text { if firms have stated that the competition indicator 'product / } \\
\text { services are fast obsolete' is very relevant or relevant }\end{array}$ \\
\hline $\begin{array}{l}\text { Competition: Strong international } \\
\text { competitors }\end{array}$ & $\begin{array}{l}1 \text { if firms have stated that the competition indicator 'strong } \\
\text { competition due to foreign competitors' is very relevant or } \\
\text { relevant }\end{array}$ \\
\hline $\begin{array}{l}\text { Firms with foreign R\&D x Strong } \\
\text { international competition }\end{array}$ & $\begin{array}{l}1 \text { if the firm has R\&D labs in Germany and at least one R\&D } \\
\text { lab abroad and experienced strong international competition } \\
\text { due to foreign competitors }\end{array}$ \\
\hline
\end{tabular}




\subsection{Descriptive Statistics}

Our estimation sample that we retain from merging the information of two surveys and removing firms with missing values consists of 1364 firms. Table 6 in the Appendix shows the distributional characteristics of the estimation sample with respect to size, industry and innovator status. It turns out that the distributions quite well reflect the ones of the total samples in 2005 and 2008 and do not give any obvious cause for selectivity concerns in this respect.

The descriptive statistics that are given in Table 7 in the Appendix elicit the degree of internationalisation in German companies. Despite the increasing trend to internationalise R\&D in Germany (Rammer and Schmiele, 2008), it turns out that firms still predominately perform R\&D in their home country. 28\% of the firms carried out R\&D activities only within Germany whereas $17 \%$ of the sample firms conducted R\&D activities in their home country as well as abroad. Nearly $50 \%$ of the firms that have established R\&D facilities abroad run one foreign $R \& D$ centre ( $8 \%$ of sampled firms). About $5 \%$ of firms with international $R \& D$ activities have chosen locations in two or three foreign countries whereas approximately $3 \%$ of the sampled firms set up R\&D laboratories in four or more countries abroad. The sample further includes about 38\% firms without any innovation activities. The reference group in our estimations represents firms that are involved in innovation project without performing own intramural R\&D (18\%).

Since profitability is a categorical variable in the data set, Figure 1 indicates the distribution of profitability across different groups according to their innovation strategy. It turns out among firms with domestic and foreign $R \& D$ the proportion of firms in each of the upper three classes is larger than for the other three groups. A Pearson test on independence of profitability and innovation strategy rejects the null hypothesis that both variables are independent. As we will show in the next section, the estimated average return on sales turns out to be $5.6 \%$ in our sample. 
Figure 1: Distribution of Profitability by Innovation Strategy

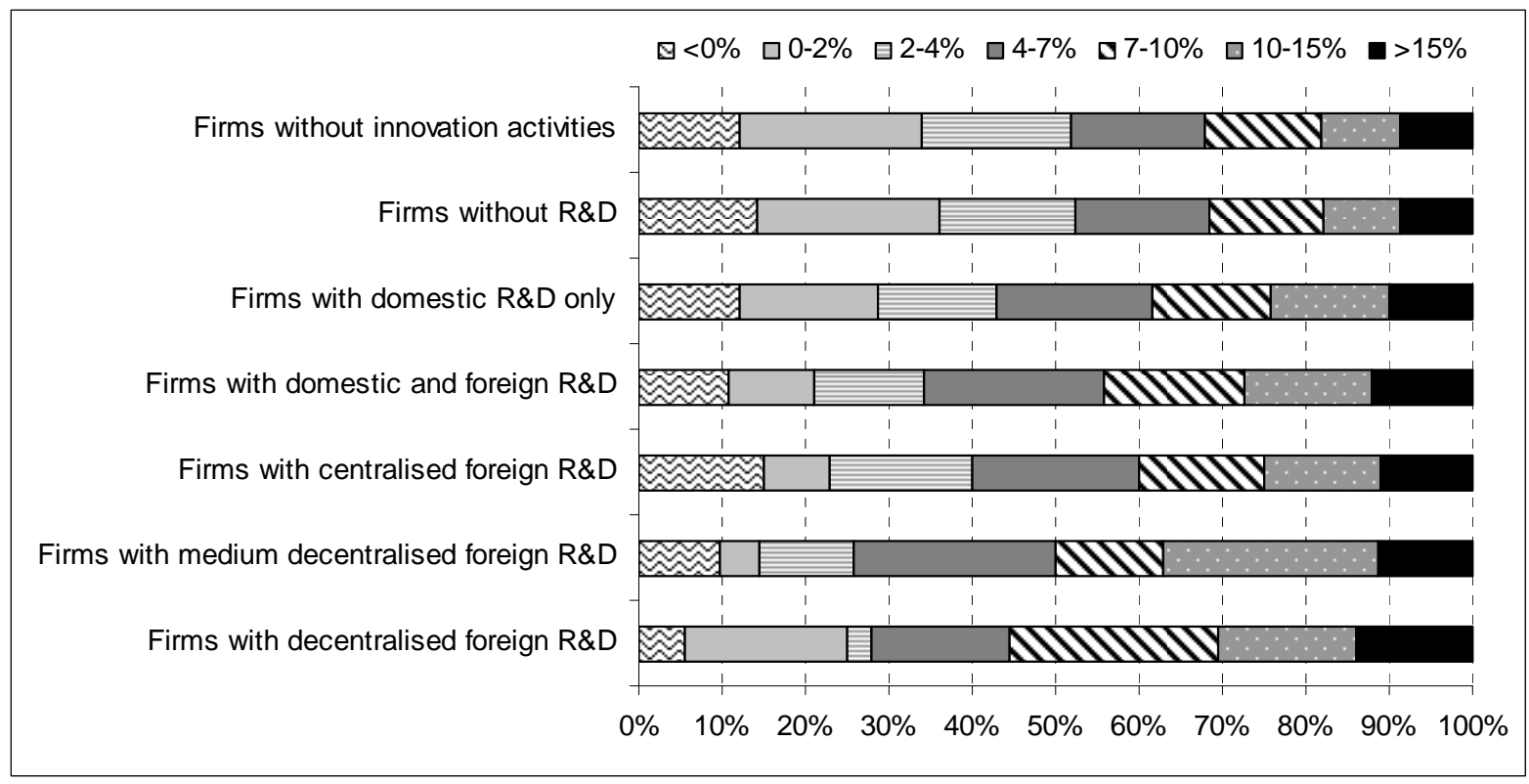

Note: The Pearson test on independence reject the null hypothesis that profitability and innovation strategy are independent variables at a 5\% level (test statistic when we account for the first four innovation strategies: $\chi^{2}(18)=33.35$ and p-value of 0.015 ; test statistic when we account for the first and last three innovation strategies: $\chi^{2}(30)=52.72$ and p-value of 0.006$)$.

\subsection{Estimation Method}

Let $y_{i}^{*}$ denote firm's profitability. We assume that it depends on the observables explanatory variables explained in section 3.3 and summarized in the row vector $x_{i}$ and on observable variables summarized in the idiosyncratic error $\varepsilon_{i}$ in the following way: ${ }^{3}$

$y_{i}^{*}=x_{i} \beta+\varepsilon_{i} \quad i=1, \ldots, N \quad$ and $\varepsilon \mid x \sim N\left(0, \sigma^{2}\right)$

$\mathrm{N}$ is the number of firms. Unfortunately, we do not observe true $y_{i}^{*}$, but only the intervalcoded profitability $y_{i}$. The structure of our endogenous variable thus determines the estimation method. An ordered probit model would have been a possible way to estimate the influence of domestic and foreign $R \& D$ activities on the return of sales. But since the thresholds of profit margins are given in the survey, we do not need to estimate them as an ordered probit estimation would do. Therefore, it is eligible to use an interval regression with known thresholds. In this model, the parameters $\beta$ and the variance $\sigma^{2}$ can be estimated by maximum likelihood (for more details, see Wooldridge 2002, p. 508). The main advantage of this approach is that, given the threshold values, the estimated coefficients can be directly 
interpreted as marginal effect like in a linear regression model and unlike in ordinal probit models with unknown thresholds, where the estimated parameters are always scaled by the normalised variance (Czarnitzki and Kraft, 2010).

To check for the robustness of the estimated coefficients, we estimate the model by gradually enhancing the model specification. The first estimation model is our baseline model, which observes the effects of innovation strategy (firms with domestic and foreign $R \& D$, with domestic $R \& D$ only and with no innovation activities) on firm profitability, when we only control for firm size. In the second model we include additional firm-level variables such as marketing and organisation innovation activities, market share information, range of product diversity, capital intensity, firm ownership status and engagement on international markets. In the third model, firm level information about the competitive nature of the market and industry dummies is incorporated. In the fourth estimation model we additionally account for past profitability. Specification five tests the hypothesis H3 by interacting foreign $R \& D$ and strength of foreign competition. The final specification subdivides firms with international R\&D by their extent of international R\&D activities into three categories and keeps all other variables from the fourth estimation.

\section{Empirical Results}

The results of six different estimation models are shown in Table 3. The first striking result is that both firms with domestic R\&D activities as well as firms with international (domestic \& foreign) R\&D activities show a significantly higher profitability as measured by the return on sales. It can be seen that these profitability effects are consistently significant across all model specifications I-V, even after controlling for firm size, past profitability and many other firmlevel variables. Whereas the magnitude of the effect of domestic R\&D is nearly unaltered as a result of the inclusion of additional explanatory variables, the effect of foreign $R \& D$ is getting somewhat smaller (it declines from 2.99 to 1.87). This implies that the observed higher profitability of firms with foreign R\&D activities in the first specification can in part be explained by other variables such as past profitability, group status, industry or market share. As already explained, in the ordered probit model with known thresholds the estimated coefficients can be interpreted as marginal effects like in the standard linear regression model. Based on model IV, the results demonstrate that purely domestic R\&D activities raise return

\footnotetext{
${ }^{3}$ For simplicity, we neglect the time indices of all variables.
} 
on sales by roughly $1 \%$ point. Firms that perform R\&D activities also abroad achieve a profit margin that is roughly $1.9 \%$ points higher compared to innovative firms without own R\&D. To assess whether this effect is large we compare it with the average return on sales. Estimating the model with a constant only yields an estimate of the average unconditional profitability which in our sample amounts to $5.57 \%$. Compared to that overall figure, an increase of $1.9 \%$ point seems to be relatively large. This is also true compared to the effect of other binary variables such as ownership or export.

More importantly with respect to our research question, the positive profitability effect is significantly stronger for firms with both domestic and global R\&D activities than for firms carrying out solely domestic R\&D. As depicted in Table 3, we tested on statistical equality of both coefficients but rejected the hypothesis that they are equal. The dominant influence of foreign R\&D is consistent across all models I-IV. The results thus confirm hypothesis H1a which states that the benefits of international knowledge sourcing outweigh the operational costs of foreign R\&D activities as well as the risks of IP losses.

Based on their theoretical model, Sanna-Radaccio and Veugelers (2007) stated that the risk of knowledge leakage increases and thus profitability declines with strong product market competition in foreign markets. To test this hypothesis (H3), we interact foreign $R \& D$ activities with a variable indicating the strength of foreign competitors in model V. We find the expected negative sign of the interaction term; however it turns out to be not significant. Hence, we cannot support hypothesis H3.

In our last model VI we examine the effect of international dispersed R\&D activities on firm profitability. The estimation elicits some interesting results. Only medium-centralised firms with two or three R\&D locations abroad and decentralised firms with R\&D in four or more countries make significantly higher profits out of their international R\&D ventures. Compared to firms conducting purely domestic $R \& D$, this difference is again significantly larger. On the contrary, we do find a positive but not significant effect for firms having just one foreign R\&D site. Firms with centralized foreign $R \& D$ activities do not outperform domestic R\&D performers, and they perform significantly worse compared to firms with medium centralised and decentralised foreign R\&D. ${ }^{4}$ Our finding indicates that firms with just one R\&D location abroad either absorb less knowledge from their foreign environment and/or that they failed to establish efficient knowledge transfer and coordination mechanisms. Since the data at hand do not provide information on such mechanisms we admittedly cannot differentiate between

\footnotetext{
${ }^{4}$ Compared to firms with decentralized R\&D, the effect is significant only at the $12 \%$ level.
} 
these explanations. But obviously, firms with more R\&D locations abroad have learned how to effectively manage those ventures. By and large, our results are consistent with hypothesis H2a postulating that profitability increases with the number of foreign $R \& D$ locations.

Another interesting finding is that the gain in profitability is larger for firms with two or three R\&D locations abroad, which we labelled medium centralised foreign innovators $(+3.5 \%$ points), than for firms that innovate in four or more different countries ( $+2.7 \%$ points). Though we cannot prove that this difference is statistically significant in our sample, it gives at least some indication that the relationship between the degree of R\&D internationalisation and profitability might be inverse u-shaped. This would be consistent first with the observation of Gassmann and von Zedtwitz (1999) who reported that MNEs tend to recentralise international $R \& D$ activities and rather establish an integrated $R \& D$ network with a smaller number of leading R\&D labs and second with a recent finding showing that the relationship between innovation outcome and the degree of internationalisation is inverse ushaped (Peters and Schmiele 2010). All in all, this question needs to be addressed in future research.

As for our control variables, we find that firm performance is negatively related to firm size. This result seems surprising since the literature provides evidence that firm size increases the likelihood of doing innovation activities abroad (Schmiele, 2009) but reduces the outlook of a higher return of sales. The estimation further provides evidence that firm profitability is highly persistent over time. The coefficients of past profitability are highly significant and increasing in magnitude across the profitability categories. Hence, firms that had a higher profitability in the past also make significantly higher return on sales in the current period 2008. We also find that firms operating in markets where products become rapidly obsolete due to strong technological competition earn smaller profit margins. On the other hand, firms having a higher market share and a more diversified product range can enhance their performance. 
Table 3: Effect of Domestic and Foreign $R \& D$ on Future Profitability

\begin{tabular}{|c|c|c|c|c|c|c|}
\hline & \multicolumn{6}{|c|}{ Dep. Var.: Profits (Return on Sales) } \\
\hline & I & II & III & IV & $\mathrm{V}$ & VI \\
\hline \multicolumn{7}{|l|}{ Innovation Strategy } \\
\hline \multirow[t]{2}{*}{ Firms without innovation activities } & -0.090 & -0.127 & 0.004 & 0.247 & 0.254 & 0.226 \\
\hline & $-(0.476)$ & $(0.482)$ & $(0.483)$ & $(0.416)$ & $(0.416)$ & $(0.416)$ \\
\hline \multirow[t]{2}{*}{ Firms with domestic R\&D only } & $1.185 * *$ & $1.081 * *$ & $0.955 *$ & $1.001 * *$ & $0.994 * *$ & $1.026 * *$ \\
\hline & $-(0.502)$ & $(0.503)$ & $(0.51)$ & $(0.447)$ & $(0.448)$ & $(0.448)$ \\
\hline \multirow[t]{2}{*}{ Firms with domestic and foreign R\&D } & $2.993 * * *$ & $2.347 * * *$ & $2.116 * * *$ & $1.873 * * *$ & $2.012 * * *$ & - \\
\hline & $(0.640)$ & $(0.656)$ & $(0.703)$ & 0.600 & $(0.689)$ & \\
\hline \multirow[t]{2}{*}{ Firms with centralised foreign R\&D } & - & - & - & - & - & 1.134 \\
\hline & & & & & & $(0.694)$ \\
\hline \multirow[t]{2}{*}{ Firms w. medium decent. foreign $R \& D$} & - & - & - & - & - & $3.477 * * *$ \\
\hline & & & & & & $(0.879)$ \\
\hline \multirow[t]{2}{*}{ Firms. with decentralised foreign R\&D } & - & - & - & - & - & $2.650 * * *$ \\
\hline & & & & & & $(0.964)$ \\
\hline \multirow{2}{*}{$\begin{array}{l}\text { Firms with foreign R\&D x Strong } \\
\text { international competition }\end{array}$} & - & - & - & - & -0.348 & - \\
\hline & & & & & $(0.794)$ & \\
\hline \multicolumn{7}{|l|}{ Control variables } \\
\hline \multirow[t]{2}{*}{ Firm size } & $-0.312 * * *$ & $-0.516 * * *$ & $-0.488 * * *$ & $-0.461 * * *$ & $-0.462 * * *$ & $-0.475 * * *$ \\
\hline & $(-0.090)$ & $(-0.113)$ & $(0.114)$ & $(0.100)$ & $(0.100)$ & $(0.102)$ \\
\hline \multirow[t]{2}{*}{ Marketing innovation } & - & -0.186 & -0.081 & -0.314 & -0.296 & -0.336 \\
\hline & & $(0.397)$ & $(0.403)$ & $(0.336)$ & $(0.337)$ & $(0.340)$ \\
\hline \multirow[t]{2}{*}{ Organisation innovation } & - & 0.036 & 0.026 & 0.133 & 0.153 & 0.124 \\
\hline & & $(0.391)$ & $(0.394)$ & $(0.337)$ & $(0.340)$ & $(0.341)$ \\
\hline \multirow[t]{2}{*}{ Exporter } & - & 0.024 & -0.037 & 0.106 & 0.095 & 0.069 \\
\hline & & $(0.385)$ & $(0.414)$ & $(0.348)$ & $(0.349)$ & $(0.351)$ \\
\hline \multirow[t]{2}{*}{ Capital intensity } & - & 0.021 & 0.056 & -0.020 & -0.020 & -0.043 \\
\hline & & $(0.096)$ & $(0.097)$ & $(0.082)$ & $(0.082)$ & $(0.082)$ \\
\hline \multirow[t]{2}{*}{ Market share } & - & $0.019 * *$ & $0.019 * *$ & $0.015 * *$ & $0.015 * *$ & $0.016 * *$ \\
\hline & & $(0.008)$ & $(0.008)$ & $(0.007)$ & $(0.007)$ & $(0.007)$ \\
\hline \multirow[t]{2}{*}{ Market share censored } & - & 0.072 & 0.060 & 0.133 & 0.129 & 0.127 \\
\hline & & $(0.508)$ & $(0.506)$ & $(0.436)$ & $(0.436)$ & $(0.436)$ \\
\hline \multirow[t]{2}{*}{ Market share missing } & - & $0.921 * *$ & $0.843 *$ & 0.529 & 0.524 & 0.487 \\
\hline & & $(0.461)$ & $(0.471)$ & $(0.407)$ & $(0.407)$ & $(0.417)$ \\
\hline Degree of product diversification & - & $0.312 * * *$ & $0.319 * * *$ & $0.409 * * *$ & $0.411 * * *$ & $0.431 * * *$ \\
\hline & & $(0.097)$ & $(0.096)$ & $(0.126)$ & $(0.128)$ & $(0.130)$ \\
\hline National group & - & -0.086 & -0.078 & -0.152 & -0.148 & -0.060 \\
\hline & & $(0.486)$ & $(0.480)$ & $(0.405)$ & $(0.404)$ & $(0.404)$ \\
\hline Internat. group with German HQ & - & $1.438 * *$ & $1.266 *$ & 0.147 & 0.154 & 0.069 \\
\hline & & $(0.665)$ & $(0.670)$ & $(0.576)$ & $(0.575)$ & $(0.585)$ \\
\hline Internat. group with $\mathrm{HQ}$ abroad & - & $2.356 * * *$ & $2.213 * * *$ & $1.421 * *$ & $1.387 * *$ & $1.457 * *$ \\
\hline & & $(0.793)$ & $(0.789)$ & $(0.676)$ & $(0.681)$ & $(0.677)$ \\
\hline Fast obsoletion & - & - & $-1.187 * *$ & $-1.229 * * *$ & $-1.231 * * *$ & $-1.175 * * *$ \\
\hline & & & $(0.475)$ & $(0.413)$ & $(0.414)$ & $(0.416)$ \\
\hline Strong international competitors & - & - & 0.249 & 0.463 & 0.524 & 0.414 \\
\hline & & & $(0.377)$ & $(0.322)$ & $(0.351)$ & $(0.329)$ \\
\hline High R\&D-intensive manuf. & - & - & $1.734 * *$ & 1.083 & 1.072 & $1.177 *$ \\
\hline & & & $(0.802)$ & $(0.690)$ & $(0.691)$ & $(0.710)$ \\
\hline Medium R\&D-intensive manuf. & - & - & 0.803 & $1.163 * *$ & $1.168 * *$ & $1.099 *$ \\
\hline & & & $(0.674)$ & $(0.577)$ & $(0.577)$ & $(0.589)$ \\
\hline Low R\&D-intensive manuf. & - & - & $0.814 *$ & $0.648 *$ & $0.644 *$ & $0.671 *$ \\
\hline & & & $(0.462)$ & $(0.391)$ & $(0.391)$ & $(0.392)$ \\
\hline Knowledge-intensive services & - & - & $1.495 * * *$ & 0.747 & 0.754 & 0.687 \\
\hline & & & $(0.564)$ & $(0.481)$ & $(0.481)$ & $(0.485)$ \\
\hline
\end{tabular}


Table 3: Effect of Domestic and Foreign R\&D on Future Profitability (continued)

\begin{tabular}{|c|c|c|c|c|c|c|}
\hline & \multicolumn{6}{|c|}{ Dep. Var.: Profits (Return on Sales) } \\
\hline & $\mathrm{I}$ & II & III & IV & $\mathrm{V}$ & VI \\
\hline \multicolumn{7}{|l|}{ Past profitability } \\
\hline Previous profits up to $2 \%$ & - & - & - & $\begin{array}{r}0.834 \\
(0.524)\end{array}$ & $\begin{array}{r}0.838 \\
(0.524)\end{array}$ & $\begin{array}{r}0.789 \\
(0.529)\end{array}$ \\
\hline Previous profits up to $4 \%$ & - & - & - & $\begin{array}{l}2.863 * * * \\
(0.553)\end{array}$ & $\begin{array}{l}2.868 * * * \\
(0.554)\end{array}$ & $\begin{array}{l}2.736 \text { *** } \\
(0.559)\end{array}$ \\
\hline Previous profits up to $7 \%$ & - & - & - & $\begin{array}{l}4.109 * * * \\
(0.549)\end{array}$ & $\begin{array}{l}4.114^{* * *} \\
(0.549)\end{array}$ & $\begin{array}{l}4.035^{* * * *} \\
(0.556)\end{array}$ \\
\hline Previous profits up to $10 \%$ & - & - & - & $\begin{array}{l}6.089 * * * \\
(0.625)\end{array}$ & $\begin{array}{l}6.091^{* * *} \\
(0.625)\end{array}$ & $\begin{array}{l}5.988 * * * \\
(0.628)\end{array}$ \\
\hline Previous profits up to $15 \%$ & - & - & - & $\begin{array}{l}6.965 \text { *** } \\
(0.685)\end{array}$ & $\begin{array}{l}6.965 \text { *** } \\
(0.685)\end{array}$ & $\begin{array}{l}6.870 \text { *** } \\
(0.698)\end{array}$ \\
\hline Previous profits more than $15 \%$ & - & - & - & $\begin{array}{l}11.400 * * * \\
(0.828)\end{array}$ & $\begin{array}{l}11.396 * * * \\
(0.828)\end{array}$ & $\begin{array}{l}11.423 \text { *** } \\
(0.831)\end{array}$ \\
\hline Previous profits missing & - & - & - & $\begin{array}{l}4.394 * * * \\
(0.660)\end{array}$ & $\begin{array}{l}4.395 \text { *** } \\
(0.660)\end{array}$ & $\begin{array}{l}4.315 \text { *** } \\
(0.661)\end{array}$ \\
\hline constant & $\begin{array}{l}6.226 * * * \\
(-0,558) \\
\end{array}$ & $\begin{array}{l}5.904 \text { *** } \\
(0.783) \\
\end{array}$ & $\begin{array}{l}5.179 * * * \\
(0.86)\end{array}$ & $\begin{array}{r}1.235 \\
(0.835) \\
\end{array}$ & $\begin{array}{r}1.211 \\
-(0.840) \\
\end{array}$ & $\begin{array}{r}1.277 \\
(0.840) \\
\end{array}$ \\
\hline Sigma & $5.971 * * *$ & $5.895 * * *$ & $5.856 * * *$ & $4.980 * * *$ & $4.980 * * *$ & $4.968 * * *$ \\
\hline LL & -2701.5 & -2685.6 & -2678.3 & -2478.9 & -2478.8 & -2409.9 \\
\hline W_all & $29,57(4) * * * \epsilon$ & $3,62(15) * * *$ & $6,96(21)^{* * *}$ & $5,58(28) * * *$ & $5,71(29) * *$ & $1,82(30) * * *$ \\
\hline No. of observations & 1364 & 1364 & 1364 & 1364 & 1364 & 1329 \\
\hline
\end{tabular}

Note: *, ** and *** indicate significance at the $10 \%, 5 \%$ and $1 \%$ level.

Table 4: Tests on Equality of the Estimated Coefficients

\begin{tabular}{|l|ccccc|}
\hline $\begin{array}{l}\text { Tests on equality of the estimation coefficients for the } \\
\text { respective equation }\end{array}$ & I II & III & IV & V \\
\hline domestic R\&D = foreign R\&D & $0.002 * * *$ & $0.034^{* *}$ & $0.061^{*}$ & $0.098^{*}$ & 0.111 \\
domestic R\&D = centralised foreign R\&D & - & - & - & & 0.867 \\
domestic R\&D = medium decentralised foreign R\&D & - & - & - & - & $0.003^{* * *}$ \\
domestic R\&D = decentralised foreign R\&D & - & - & - & $0.075^{*}$ \\
centralised foreign R\&D = medium decentral. foreign R\&D & - & - & - & $0.009^{* * *}$ \\
centralised foreign R\&D = decentralised foreign R\&D & & & & - & 0.120 \\
med.decent. foreign R\&D = decentralised foreign R\&D & - & - & - & 0.423 \\
\hline
\end{tabular}

Note: $*$, ** and $* * *$ indicate significance at the $10 \%, 5 \%$ and $1 \%$ level.

The results furthermore demonstrate that firms belonging to a group with headquarter abroad show higher profitability than all other firms. On the one hand, it is not surprising that they outperform unaffiliated firms or firms belonging to a national group since it is likely that the best performing foreign firms enter the German market by acquiring German firms and that they transfer efficiency gains to their subsidiaries in Germany (Dunning 1981; Helpman et al. 2004). Based on this rationale, however, it is surprising that they perform much better than firms belonging to German multinationals. The coefficients of the industry dummies show that in general firms from all three manufacturing industries achieve higher return on sales than service firms, including knowledge-intensive services firms. 
To check the robustness of our results, we perform several sensitivity analyses which are summarized in Table 5. First, we investigate whether the results hold when we choose a different time lag. It turns out that the main conclusions still hold when we use a two-year lag for profitability. However, the estimated effect of foreign $R \& D$ is smaller compared to our previous results. This is not surprising because, as already said, it takes some time to translate research efforts into innovation outcome and thus to make profits out of R\&D activities. Interestingly, firms with domestic R\&D show a positive but not significant coefficient in this estimate. This could point towards the fact that foreign R\&D also increases the speed of translating research into new products or processes. Using a one-year time lag, it turns out that neither domestic nor foreign $R \& D$ activities raise profitability. This is again consistent with the view that $R \& D$ is a long-term investment.

Second, we check what happens when we exclude German firms that belong to a foreign multinational group. Foreign R\&D activities of those firms might be quite different and might drive our previous results on the effectiveness of foreign R\&D. However, we find the result of a stimulating effect of foreign $R \& D$ activities confirmed in the reduced sample.

Next, we exclude very small firms (less than 100 employees). These firms rarely have foreign R\&D activities and though we control for firm size in our main specifications, the results on foreign R\&D activities might in part also reflect a size effect. However, the results corroborate our previous findings.

Finally, we check for heteroskedasticity. We specify group-wise multiplicative heteroskedasticity of the form $\sigma_{i}=\sigma \exp \left(z_{i} \gamma\right)$, where z denotes a vector of variables possibly causing heteroskedasticity. Originally, we use all survey stratification variables (i.e. dummy variables for East Germany, 25 industries and 8 size classes), since stratification of the survey leads to heteroskedastic error terms. However, it turns out that the dummy for East Germany was not significant and we decide to leave it out. In the heteroskedastic ordered probit model the parameters $\gamma$ have to be estimated as well. The likelihood ratio test rejects the assumption of homoskedasticity. However, the overall results are nearly unaltered compared to the homoskedastic model. 
Table 5: Robustness Checks

\begin{tabular}{|c|c|c|c|c|c|c|c|c|}
\hline \multirow[b]{2}{*}{ Firms without innovation activities } & \multicolumn{2}{|c|}{$\begin{array}{c}\text { Only Firms with inno- } \\
\text { vation activities in } 2005\end{array}$} & \multicolumn{2}{|c|}{\begin{tabular}{|c|} 
Only Firms with more than \\
100 employees \\
\end{tabular}} & \multicolumn{2}{|c|}{ Profits 2 years ahead } & \multicolumn{2}{|c|}{ Heteroskedasticity estimation } \\
\hline & - & - & $\begin{array}{l}1.187 * \\
(0.671)\end{array}$ & $\begin{array}{r}1.085 \\
(0.673)\end{array}$ & $\begin{array}{r}0.178 \\
(0.380)\end{array}$ & $\begin{array}{r}0.157 \\
(0.380)\end{array}$ & $\begin{array}{r}0.070 \\
(0.378)\end{array}$ & $\begin{array}{r}0.042 \\
(0.380)\end{array}$ \\
\hline Firms with domestic R\&D only & $\begin{array}{l}1.101^{* *} \\
(0.462)\end{array}$ & $\begin{array}{l}1.144^{* *} \\
(0.463)\end{array}$ & $\begin{array}{r}1.010 \\
(0.654)\end{array}$ & $\begin{array}{r}0.979 \\
(0.655)\end{array}$ & $\begin{array}{r}0.484 \\
(0.397)\end{array}$ & $\begin{array}{r}0.484 \\
(0.397)\end{array}$ & $\begin{array}{c}0.806 * * \\
(0.407)\end{array}$ & $\begin{array}{c}0.837 * * \\
(0.409)\end{array}$ \\
\hline Firms with domestic and foreign R\&D & $\begin{array}{l}2.080 * * * \\
(0.641)\end{array}$ & - & - & $\begin{array}{l}2.553 * * * \\
(0.766)\end{array}$ & $\begin{array}{l}1.464 \text { *** } \\
(0.541)\end{array}$ & - & $\begin{array}{l}1.696^{* * *} \\
(0.551)\end{array}$ & - \\
\hline Firms with centralised foreign R\&D & - & $\begin{array}{c}1.270 * \\
(0.721)\end{array}$ & - & $\begin{array}{l}1.745^{* * *} \\
(0.857)\end{array}$ & - & $\begin{array}{l}1.265^{* *} \\
(0.632)\end{array}$ & - & $\begin{array}{c}1.143 * \\
(0.643)\end{array}$ \\
\hline Firms with medium decentralised foreign R\&D & - & $\begin{array}{l}3.765 * * * \\
(0.920)\end{array}$ & - & $\begin{array}{l}3.523 * * * \\
(1.019)\end{array}$ & - & $\begin{array}{l}1.776 \text { ** } \\
(0.775)\end{array}$ & - & $\begin{array}{l}3.117 * * * \\
(0.833)\end{array}$ \\
\hline Firms. with decentralised foreign R\&D & - & $\begin{array}{l}3.014 \text { *** } \\
(1.012)\end{array}$ & - & $\begin{array}{l}2.994^{* * *} \\
(1.084)\end{array}$ & - & $\begin{array}{l}2.075^{* *} \\
(0.872)\end{array}$ & - & $\begin{array}{l}2.304^{* *} \\
(1.036)\end{array}$ \\
\hline domestic $R \& D=$ foreign $R \& D$ & $0.076 *$ & - & $0.013 * *$ & - & $0.037 * *$ & - & $0.070 *$ & - \\
\hline domestic $\mathrm{R} \& \mathrm{D}=$ centralised foreign $\mathrm{R} \& \mathrm{D}$ & - & 0.847 & - & 0.298 & - & 0.171 & - & 0.609 \\
\hline domestic $R \& D=$ medium decentralised foreign $R \& D$ & - & $0.002 * * *$ & - & $0.004 * * *$ & - & $0.076 *$ & - & $0.004 * * *$ \\
\hline domestic R\&D = decentralised foreign R\&D & - & $0.048 * *$ & - & $0.036 * *$ & - & 0.054 & - & 0.140 \\
\hline centralised foreign $R \& D=$ medium decent. foreign $R \& D$ & - & $0.005 * * *$ & - & $0.051 *$ & - & 0.515 & - & $0.024 * *$ \\
\hline centralised foreign $\mathrm{R} \& \mathrm{D}=$ decentralised foreign $\mathrm{R} \& \mathrm{D}$ & - & $0.078 *$ & - & 0.213 & - & 0.347 & - & 0.268 \\
\hline med.decent. foreign R\&D = decentralised foreign $R \& D$ & - & 0.469 & - & 0.603 & - & 0.751 & - & 0.466 \\
\hline $\begin{array}{l}\text { ln sigma } \\
\text { Industry dummies } \\
\text { Size dummies } \\
\text { LR-Test } \\
\end{array}$ & & & & & & & $\begin{array}{c}\operatorname{chi} 2(24)=91.42 * * * \\
\operatorname{chi} 2(7)=17.64 * * \\
\operatorname{chi} 2(31)=109.04 * * *\end{array}$ & $\begin{array}{l}\operatorname{chi} 2(24)=84.07 * * * \\
\operatorname{chi} 2(7)=19.79 * * * \\
\operatorname{chi} 2(31)=104.38 * * *\end{array}$ \\
\hline No. of observations & 853 & 818 & 585 & 553 & 1361 & 1326 & 1364 & 1329 \\
\hline
\end{tabular}

Note: $*, * *$ and $* * *$ indicate significance at the $10 \%, 5 \%$ and $1 \%$ level. The full set of control variables was included in the regressions but not reported. Ln sigma indicates the results for the variance estimation. We only report tests on joint significance of industry and size dummies of this equation. 


\section{Conclusion}

This paper aimed to evaluate the relationship between costs and benefits that result from international R\&D activities. From a theoretical point of view there is no clear indication whether the gains of R\&D activities abroad in terms of a presumably increasing innovation output and additional knowledge creation outweigh the pains of $R \& D$ internationalisation related to financial, organisational costs, foregone economies of scale and scope and outgoing knowledge spillovers. We have utilised a comprehensive data set which incorporates cross section and time series information to carry out an empirical analysis on this matter. R\&D internationalisation is a firm strategy that is adapted and extended by an increasing number of firms. Hence, we furthermore investigated how firms that have spread their R\&D activities across multiple countries differ in their profitability in comparison to firms that have chosen a moderate number of countries in which they operate $R \& D$ activities.

All in all, our results tell a rather clear story. We consistently find that R\&D activities abroad are conducive to firms' profitability. We likewise ascertain a stimulating effect for firms with purely domestic R\&D activities. But the results confirm that firms with both domestic and international R\&D experience a stronger effect on return on sales. We can therefore conclude that firms which innovate globally are not only able to realise the benefits of these international ventures but that they are also able to limit the costs and risks. We furthermore provide evidence that firms with internationally more dispersed $R \& D$ operations achieve higher return on sales. Though due to data limitations the evidence is admittedly weak, the estimation results lead us furthermore to the conclusion that a moderate number of $R \& D$ locations abroad seems to be most conducive to profitability. Firms which have established R\&D laboratories in two or three countries receive the highest return from their foreign $R \& D$ efforts. Firms with four or more R\&D locations abroad seem to achieve lower profitability gains than medium centralized firms, but the gain is still about twice as large as the one of firms performing solely domestic R\&D. As already pointed out, further research on the hypothesis of an inverse U-shaped relationship between the degree of $R \& D$ internationalisation and profitability seems to be necessary.

One aspect of the analysis is worthy to note. In our sample, international R\&D performers always carry out R\&D at home as well. This implies that the observed higher profitability of firms pursuing an international R\&D strategy might be attributed to two different sources. 
Either $R \& D$ abroad itself is more beneficial than domestic $R \& D$ or foreign $R \& D$ is as beneficial as domestic R\&D but firms may realise additional synergy (complementarity) effects if they perform R\&D at home and abroad. Due to the above mentioned data constraints we unfortunately cannot distinguish between these two sources. This is an open question that remains for future research.

One academic intention of this paper was to fill an essential gap in the literature. Our results draw attention to the extensive research about the motives, organisation and management of international R\&D. So far there have been few efforts to describe the benefits of global $R \& D$ centres but these attempts have often used patent data which have several limitations to measure benefits (Griliches, 1990). Furthermore, these studies have been narrowly focussed either on the costs or on the benefits of international $R \& D$. This study was aimed to combine both views and to provide empirical evidence to managers who face both perspectives in their business. To conclude, R\&D location matters for profitability. Sourcing knowledge abroad is beneficial to firms' operational profits and indicates that firms which undertake global R\&D efforts may also grow faster than firms that rely on domestic R\&D. However, there is a threshold in the number of locations beyond which firms cannot increase their profitability anymore (and might experience a decrease in profits) 


\section{References}

Ambos, B., Ambos, T.C. (2009), Location Choice, Management and Performance of International R\&D Investments in Peripheral Economies. International Journal of Technology Management, 48, 1, 24-41.

Andersson, U., Pedersen, T. (2010), Organizational Design Mechanisms for the R\&D Function in a World of Offshoring, Scandinavian Journal of Management, 26, 431-438.

Argyres, N.S., Silverman, B.S. (2004), R\&D, Organization Structure, and the Development of Corporate Technological Knowledge, Strategic Management Journal, 25, 929-958.

Bernard, A.B., Jensen, J.B. (1999), Exceptional Exporter Performance: Cause, Effect, or Both?, Journal of International Economics, 47(1), 1-25.

Branstetter, L.G. (2001), Are Knowledge Spillovers International or Intranational in Scope?, Journal of International Economics; 53(1), 53-79.

Coase, R.H. (1937), The Nature of the Firm, Economica, 4(16), 386-405.

Cohen, W.M., Levinthal, D.A. (1989), Innovation and Learning: The Two Faces of R\&D, The Economic Journal, 99, 569-596.

Czarnitzki, D., Kraft, K. (2010), On the Profitability of Innovative Assets, Applied Economics, 42(15), 1941-1953.

De Loecker, J. (2007), Do Exports Generate Higher Productivity? Evidence from Slovenia, Journal of International Economics 73(1), 69-98.

Dunning, J.H. (1981), International Production and the Multinational Enterprise, Allen \& Unwin, London.

Florida, R. (1997), The Globalization of R\&D: Results of a Survey of Foreign-affiliated R\&D Laboratories in the US, Research Policy, 26, 85-103.

Fors, G. (1997), Utilization of R\&D Results in the Home and Foreign Plants of Multinationals, The Journal of Industrial Economics, 45(3), 341-358.

Frost, T.S. (2001), The Geographic Sources of Foreign Subsidiaries’ Innovations, Strategic Management Journal, 22, 101-123.

Gassmann, O., Von Zedtwitz, M. (1999), New Concepts and Trends in International R\&D Organization, Research Policy, 28, 231-250.

Gande, A., Schenzler, C., Senbet, L. W. (2009), Valuation Effects of Global Diversification, Journal of International Business Studies, 40(9), 1515-1532.

Granstrand, O., Hakanson, L., Sjölander, S. (1993), Internationalization of R\&D - A Survey of Some Recent Research, Research Policy, 22, 413-430. 
Geringer. J.M., Beamish, P.W., Dacosta, R.C. (1989), Diversification Strategy and Internationalization: Implications for MNE Performance. Strategic Management Journal, 10(2), 109-119.

Geroski, P.A., Jacquemin (1988), The Persistence of Profits: A European Comparision, The Economic Journal, 98(391), 375-389.

Grant, R. M. (1996), Toward a Knowledge-Based Theory of the Firm, Strategic Management Journal, 17 (Winter Special Issue), 109-122.

Grevesen, C.W., Damanpour, F. (2007), Performance Implications of Organisational Structure and Knowledge Sharing in Multinational R\&D Networks, International Journal of Technology Management, 38(1/2), 113-136.

Griliches, Z. (1986), Productivity, R\&D and Basic Research at the Firm Level in the 1970s', American Economic Review, 76(1), 141-154.

Griliches, Z. (1990), Patent Statistics as Economic Indicators: A Survey, Journal of Economic Literature, 28(4), 1661-1707.

Hall, B.H., Lotti, F., Mairesse, J. (2009a), Innovation and Productivity in SMEs: Empirical Evidence for Italy, Small Business Economics, 33(1), 13-33.

Hall, B. H., Mairesse, J., Mohnen, P. (2009b), Measuring the Returns to R\&D, NBER Working Paper 15622, Cambridge, Mass.

Harris, F.H.deB. (1988), Capital Intensity and the Firm's Cost of Capital, Review of Economics and Statistics, 70(4), 587-594.

Helpman, E., Melitz, M.J., Yeaple, S.R. (2004), Export Versus FDI with Heterogeneous Firms, American Economic Review 94(1), 300-316.

Hitt, M.A., Hoskisson, R.E., Ireland, R.D. (1994), A Mid-Range Theory of the Interactive Effects of International and Product Diversification on Innovation and Performance, Journal of Management, 40(2), 297-326.

Hitt, M.A., Hoskisson, R.E., Kim, H. (1997), International Diversification: Effects on Innovation and Firm Performance in Product-Diversified Firms, Academy of Management Journal, 40(4), 767-798.

Hutzschenreuter, T., Voll, J. (2008), Performance Effects of „Added Cultural Distance“in the Path of International Expansion: the Case of German Multinational Enterprises, Journal of International Business Studies, 39, 53-70.

Hymer, S.H. (1976), The International Operations of National Firms: A Study of Direct Foreign Investment, MIT Press, Cambridge, MA.

Iwasa, T, Odagiri, H. (2004), Overseas R\&D, Knowledge Sourcing, and Patenting: An Empirical Study of Japanese R\&D Investment in the US, Research Policy, 33(5), 807-828. 
Jaffe, A. B., Trajtenberg, M., Henderson, R. (1993), Geographic Localization of Knowledge Spillovers as Evidenced by Patent Citations, The Quarterly Journal of Economics, 108(3), 577-598.

Kafouros, M. I., Buckley, P.J., Sharp, J. A., Wang, C. (2008), The Role of Internationalization in Explaining Innovation Performance, Technovation, 28 (1/2), 63-74.

Kay, N. (1988), The R\&D Function: Corporate Strategy and Structure, in: Technical Change and Economic Theory. Dosi, G., Freeman, C., Nelson, R., Silverberg, G., Soete, C. (eds.), Pinter: London, 283-294.

Kogut, B., Zander, U. (1995), Knowledge and the Speed of the Transfer and Imitation of Organizational Capabilities: An Empirical Test., Organization Science, 6(1), 76-92.

Kotabe, M., Srinivasan, S.S., Aulakh, P.S. (2002), Multinationality and Firm Performance: The Moderating Role of R\&D and Marketing Capabilities, Journal of International Business Studies, 33(1), 79-97.

Kuemmerle, W. (1997), Building Effective R\&D Capabilities Abroad, Harvard Business Review, 75, 61-70.

Kuemmerle, W. (1998), Optimal Scale for Research and Development in Foreign Environments - An Investigation into Size and Performance of Research and Development Laboratories Abroad, Research Policy, 27(2), 111-126.

Kumar, M.S. (1984), Growth Acquisition and Investment: An Analysis of the Growth of Industrial Firms and their Overseas Activities, Cambridge University Press, Cambridge.

Legler, H., Frietsch, R. (2007), Neuabgrenzung der Wissenswirtschaft, Forschungsintensive Industrien und wissensintensive Dienstleistungen (NIW/ISI Listen 2006), Studien zum deutschen Innovationssystem Nr.22, Bundesministerium für Bildung und Forschung (BMBF).

Leiponen, A., Helfat, C. E. (2010), Location, Decentralization, and Knowledge Sources for Innovation, Organization Science, forthcoming, (doi:10.1287/orsc.1100.0526).

Lööf, H., Heshmati, A. (2006), On the Relationship between Innovation and Performance: A Sensitivity Analysis, Economics of Innovation and New Technology, 15(4/5), 317-344.

Malecki, E.J.(1980), Corporate Organization of R and D and the Location of Technological Activities, Regional Studies, 14, 219-234.

Mansfield, E., Romero, A., Wagner, S. (1979), Foreign Trade and U.S. Research and Development, Review of Economics \& Statistics, 61(1), 49-57.

Mansfield, E. (1984), R\&D and Innovation: Some Empirical Findings, in: R\&D, Patents, Productivity. Griliches, Z. (ed.), University of Chicago Press: Chicago, 127-154.

McEvily, B., Zaheer, A. (1999), Bridging Ties: A Source of Firm Heterogeneity in Competitive Capabilities, Strategic Management Journal, 20, 1133-1156.

Morck, R., Yeung, B. (1991), Why Investors Value Multinationality, Journal of Business, 64(2), 165-187. 
Penner-Hahn, J., Shaver, M.J. (2005), Does International Research and Development Increase Patent Output? An Analysis of Japanese Pharmaceutical Firms, Strategic Management Journal, 26, 121-140.

Peteraf, M.A. (1993), The Cornerstones of Competitive Advantage: A Ressource-Based View, Strategic Management Journal, 14, 179-191.

Peters, B. (2008), Innovation and Firm Performance, ZEW Economic Studies, 38, Physica, Heidelberg.

Peters, B., Schmiele, A. (2010), The Influence of International Dispersed vs. Home-Based R\&D on Innovation Performance, ZEW Discussion Paper No.10-102, Mannheim.

Phene, A., Almeida, P. (2008), Innovation in Multinational Subsidiaries: The Role of Knowledge Assimilation and Subsidiary Capabilities, Journal of International Business Studies, 39, 901-919.

Qian, G., Li, L., Li, J., Zengming, Q. (2008), Regional Diversification and Firm Performance, Journal of International Business Studies, 39, 197-214.

Rammer, C. Schmiele, A. (2008), Schwerpunktbericht zur Innovationserhebung 2006, ZEW Dokumentation No. 08-06, Mannheim.

Rugman, A.M., Verbeke, A. (2004), A Perspective on Regional and Global Strategies of Multinational Enterprises, Journal of International Business Studies, 35(1), 3-18.

Sanna-Radaccio, F., Veugelers, R. (2007), Multinational Knowledge Spillovers with Decentralised R\&D: A Game-Theoretic Approach, Journal of International Business Studies, 38, 47-63.

Schmiele, A. (2009), Drivers for International Innovation Activities in Developed and Emerging Countries, ZEW Discussion Paper No. 09-064, Mannheim.

Sullivan, D. (1994), Measuring the Degree of Internationalization of a Firm, Journal of International Business Studies, 25(2), 325-342.

Szulanski, G. (1996), Exploring Internal Stickiness: Impediments to the Transfer of Best Practice within the Firm, Strategic Management Journal, 17, 27-43.

Todo, Y., Shimizutani, S. (2008), Overseas R\&D Activities and Home Productivity Growth: Evidence from Japanese Firm-Level Data, The Journal of Industrial Economics, 4, 752-777.

UNCTAD ed. (2005), World Investment Report 2005: Transnational Corporations and the Internationalisation of $R \& D$, New York and Geneva.

Vernon, R. (1971), Sovereignty at Bay: The Multinational Spread of U.S. Enterprises, Basic Books, New York.

Waalmaak, J.T., Eckerstein, S., Langered, B., Holmqvist, H.E.S. (1973), The Increase in Efficiency with Size of Research Teams, IEEE Transactions on Engineering Management, EM-20, 80-86. 
Wan, W.P., Hoskisson, R.E. (2003), Home Country Environments, Corporate Diversification Strategies, and Firm Performance, Academy of Management Journal, 46(1), 27-45.

Williamson, O.E. (1985), The Economic Institutions of Capitalism, Free Press, New York.

Wooldridge, J.M. (2002), Econometric Analysis of Cross Section and Panel Data, Cambridge, MA.

Yang, D. (2005), Culture Matters to Multinationals' Intellectual Property Business, Journal of World Business, 40, 281-301.

Zaheer, S. (1995), Overcoming the Liabilities of Foreignness, Academy of Management Journal, 38(2), 341-363.

Zaheer, S., Mosakowski, E. (1997), The Dynamics of the Liability of Foreignness: A Global Study of Survival in Financial Services, Strategic Management Journal, 18(6), 439-463.

Zahra, S.A., Hayton, J.C. (2008), The Effect of International Venturing on Firm Performance: The Moderating Influence of Absorptive Capacity, Journal of Business Venturing, 23, 195220. 


\section{Appendix}

Table 6: Distributional Characteristics of Samples

\begin{tabular}{|l|c|c|c|}
\hline \multirow{2}{*}{ Bistribution } & \multicolumn{2}{|c|}{ Sample } & Estimation \\
\cline { 2 - 4 } & $\mathbf{2 0 0 5}$ & $\mathbf{2 0 0 8}$ & 15.25 \\
10 size & & & 14.22 \\
$20-49$ & 17.31 & 18.47 & 14.88 \\
$50-99$ & 15.73 & 16.22 & 11.88 \\
$100-249$ & 16.89 & 18.14 & 12.02 \\
$250-499$ & 11.49 & 13.43 & 6.45 \\
$500-999$ & 12.74 & 12.70 & 4.55 \\
$>1000$ & 7.25 & 5.61 & 20.75 \\
\hline By industry & 5.73 & 4.42 & 7.33 \\
High R\&D-intensive manufacturing & 12.86 & 11.00 & 12.76 \\
Medium R\&D-intensive manufacturing & & & 39.59 \\
Low R\&D-intensive manufacturing & 7.52 & 6.94 & 20.89 \\
Knowledge-intensive services & 10.89 & 11.88 & 19.43 \\
\hline Other services & 40.04 & 38.89 & 37.49 \\
\hline By innovation activities & 20.36 & 21.33 & 62.51 \\
\hline Without innovation activities & 21.19 & 20.96 & \\
With innovation activities & & 35.71 & 64.29 \\
\hline
\end{tabular}

Notes: Samples of 2005 and 2008 includes 5187 and 7662 observations. The estimation sample 1364. 
Table 7: Descriptive Statistics

\begin{tabular}{|c|c|c|c|c|c|}
\hline No. & Explanatory Variables & Mean & Std. Dev. & Min & Max \\
\hline 1 & Firm without innovation activities & 0.375 & 0.484 & 0 & 1 \\
\hline 2 & Firms with domestic R\&D only & 0.276 & 0.447 & 0 & 1 \\
\hline 3 & Firms with domestic and foreign R\&D & 0.171 & 0.376 & 0 & 1 \\
\hline 4 & Firms with centralised foreign R\&D & 0.075 & 0.264 & 0 & 1 \\
\hline 5 & Firms with medium decentralised foreign R\&D & 0.047 & 0.211 & 0 & 1 \\
\hline \multirow[t]{2}{*}{6} & Firms. with decentralised foreign R\&D & 0.027 & 0.162 & 0 & 1 \\
\hline & Firms without R\&D (reference group) & 0.181 & 0.385 & 0 & 1 \\
\hline 7 & Foreign R\&D x Strong international competition & 0.065 & 0.246 & 0 & 1 \\
\hline 8 & Firm size & 4.671 & 2.447 & 0 & 13.041 \\
\hline 9 & Marketing innovation & 0.359 & 0.480 & 0 & 1 \\
\hline 10 & Organisation innovation & 0.374 & 0.484 & 0 & 1 \\
\hline 11 & Exporter & 0.535 & 0.499 & 0 & 1 \\
\hline 12 & Capital intensity & -2.642 & 1.894 & -9.551 & 3.827 \\
\hline 13 & Market share & 14.550 & 25.868 & 0 & 100 \\
\hline 14 & Dummy: Market share truncated & 0.192 & 0.394 & 0 & 1 \\
\hline 15 & Dummy: Market share missing & 0.278 & 0.448 & 0 & 1 \\
\hline \multirow[t]{2}{*}{16} & Degree of diversification & 1.693 & 1.623 & 1 & 50 \\
\hline & National firm, unaffiliated (reference group) & 0.565 & 0.496 & 0 & 1 \\
\hline 17 & National group & 0.163 & 0.369 & 0 & 1 \\
\hline 18 & Intern. group with German HQ & 0.191 & 0.394 & 0 & 1 \\
\hline 19 & Intern. group with HQ abroad & 0.081 & 0.272 & 0 & 1 \\
\hline 20 & High R\&D-intensive Manufacturing & 0.073 & 0.261 & 0 & 1 \\
\hline 21 & Medium R\&D-intensive Manufacturing & 0.128 & 0.334 & 0 & 1 \\
\hline 22 & Low R\&D-intensive Manufacturing & 0.396 & 0.489 & 0 & 1 \\
\hline \multirow[t]{2}{*}{23} & Knowledge-intensive services & 0.209 & 0.407 & 0 & 1 \\
\hline & Other services (reference group) & 0.194 & 0.396 & 0 & 1 \\
\hline 24 & Competition: Fast obsoletion & 0.147 & 0.354 & 0 & 1 \\
\hline 25 & Competition: Strong international competitors & 0.315 & 0.464 & 0 & 1 \\
\hline 26 & Previous profits up to $2 \%$ & 0.175 & 0.380 & 0 & 1 \\
\hline 27 & Previous profits up to $4 \%$ & 0.160 & 0.367 & 0 & 1 \\
\hline 28 & Previous profits up to $7 \%$ & 0.164 & 0.371 & 0 & 1 \\
\hline 29 & Previous profits up to $10 \%$ & 0.104 & 0.306 & 0 & 1 \\
\hline 30 & Previous profits up to $15 \%$ & 0.100 & 0.300 & 0 & 1 \\
\hline 31 & Previous profits more than $15 \%$ & 0.084 & 0.277 & 0 & 1 \\
\hline \multirow[t]{2}{*}{32} & Previous profits missing & 0.101 & 0.302 & 0 & 1 \\
\hline & Previous profits less than $0 \%$ (reference group) & 0.112 & 0.316 & 0 & 1 \\
\hline
\end{tabular}


Table 8: Correlation Matrix of Explanatory Variables (by No., see previous table)

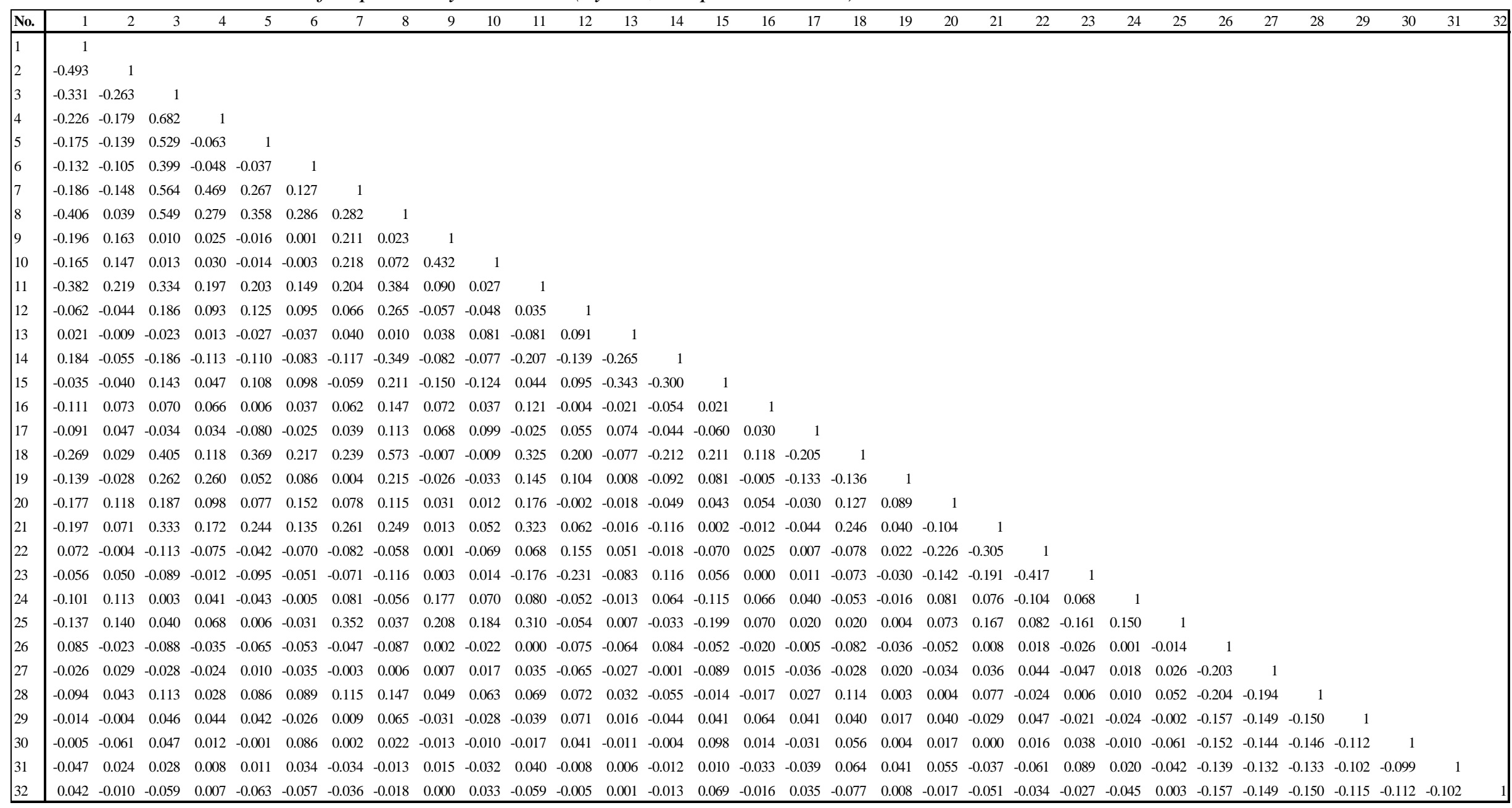

